Article - Agriculture, Agribusiness and Biotechnology

\title{
Amylase from Bacillus sp. Produced by Solid State Fermentation Using Cassava Bagasse as Starch Source.
}

Ian Mateus Gois ${ }^{1}$

https://orcid.org/0000-0003-0255-8764

\author{
Alana Mayara Santos ${ }^{1}$ \\ https://orcid.org/0000-0002-9620-8185 \\ Cristina Ferraz Silva ${ }^{1 *}$ \\ https://orcid.org/0000-0001-5194-2282
}

${ }^{1}$ Federal University of Sergipe, Department of Chemical Engineering and Industrial Chemistry, São Cristóvão, Sergipe, Brazil.

Received: 2017.08.16; Accepted: 2020.03.17.

*Correspondence: ferrazcristina@yahoo.com.br; Tel.: +55-79-3194677 (C.F.S)

\section{HIGHLIGHTS}

- Bacillus sp was capable of producing amylases, even in solid-state fermentation.

- Crueira, a solid waste, showed, indeed, potential to be used in amylases production.

- Using crueira to obtain bioproducts can attenuate some social/environmental issues.

\begin{abstract}
Amylases are enzymes involved in starch hydrolysis, generating the most diverse products, such as maltose, glucose and dextrins. This work aimed the study of the production of amylolytic enzymes via solid-state fermentation (SSF) using "crueira", an essentially starchy cassava residue, as substrate-support and Bacillus sp. as microorganism. For the implementation of the experimental part, a Central Composite Design (CCD) with three variables (initial moisture, $\mathrm{pH}$ and temperature) was made. Each test was examined at 24,48 and 72 hours by the method of starch dextrinizing activity. The optimum production conditions were $60 \%$ initial moisture, $\mathrm{pH} 6$ and $37^{\circ} \mathrm{C}$. The maximum yield was $437.76 \mathrm{U} / \mathrm{g}$ in 72 hours of fermentation. The optimum temperature of enzyme performance was $65^{\circ} \mathrm{C}$. The $\mathrm{pH}$ optimum range was 4 to 6 . The $\mathrm{Co}^{2+}, \mathrm{Ca}^{2}$ ${ }^{+}$and $\mathrm{K}^{+}$ions positively influenced the activity of enzymes and the $\mathrm{Fe}^{2+}$ ion had no effect on enzymatic activity. On the other hand, the ions $\mathrm{Hg}^{2+}, \mathrm{Zn}^{2+}, \mathrm{Cu}^{2+}, \mathrm{Mn}^{2+}$ and $\mathrm{Mg}^{2+}$ adversely influenced enzymatic activity. Therefore, producing amylases from Bacillus sp. and using crueira as a substrate is possible.
\end{abstract}

Keywords: amylases; solid-state fermentation; crueira.

\section{INTRODUCTION}

Enzymes are proteins that have catalytic activity and high specificity of substrate [1]. The industry was one of the first to explore the potential of enzymes and because of them, the production processes could be performed in a shorter time, lower temperatures and pressures or using cheap starting material [2]. Nowadays, microorganisms are the main source of enzymes, but they can be obtained from animal and plant 
sources, as well. One of the benefits of microbial enzymes is the possibility of using low-cost substrates such as agricultural residues [3]. In addition, the production yield can be enhanced optimizing the process conditions or by mutations on the microorganisms [2].

In the global enzymes market, amylases are the most commercialized due to their industrial versatility. These enzymes hydrolyze the starch molecules into glucose units and they are applied in many industrial processes such as sugar syrup production from starch, desizing of textile fabrics and brewing industries. Amylases can also be used as pharmaceuticals [1].

Brazil has progressively emerged as a major agricultural powerhouse. The country ranks among the world's five largest agricultural producers and exporters [4]. However, during the processing of agricultural products, many by-products are generated. In Brazil, agribusiness of corn, sugarcane, rice, cassava, wheat and coconut generates million tons of residue per year. Therefore, it is indispensable that new solutions for the appropriate use of those resources be created [5].

"Crueira", a solid residue from the sieving of the crushed cassava, is an important source of starch, thus a suitable substrate to produce amylolytic enzymes [6]. In addition, crueira has low added value, since it has no importance in the manufacture of food made from cassava. Therefore, attaching commercial value to crueira means generating a new source of income for family farming.

Due to the presented facts, the objective of this study was the production of bacterial amylase by solidstate fermentation using "crueira" as substrate/support, as well as the characterization of produced amylases.

\section{MATERIAL AND METHODS}

\section{Inoculum Preparation}

Bacillus sp. strain was isolated from a mangrove in Sergipe, Brazil [7]. The inoculum was prepared in a $250 \mathrm{~mL}$ Erlenmeyer flask containing $100 \mathrm{~mL}$ of culture medium $(5.0 \mathrm{~g} / \mathrm{L} \mathrm{NaCl}, 5.0 \mathrm{~g} / \mathrm{L}$ bacteriological peptone, $1.5 \mathrm{~g} / \mathrm{L}$ yeast extract and $1 \%$ soluble starch). The bacterium was transferred from a Petri dish with Nutrient Agar to the liquid culture medium with an inoculation loop under sterile condition. The inoculated culture was placed in an orbital shaker at $100 \mathrm{rpm}$ and $25^{\circ} \mathrm{C}$ for 24 hours, time needed to reach $5.0 \times 10^{7}$ viable cells $/ \mathrm{mL}$

\section{Experimental Design}

A Central Composite Design (CCD) was prepared to better understand the influence of $\mathrm{pH}$, temperature and initial moisture on amylolytic enzymes production. Central, factorial and axial points were used (Table 1) on the CCD, totaling 17 assays (Table 2).

Table 1. CCD central, factorial and axial points for each studied variable and their corresponding values.

\begin{tabular}{cccccc}
\hline Variable & $\mathbf{- 1 , 6 8}$ & $\mathbf{- 1}$ & $\mathbf{0}$ & $\mathbf{+ 1}$ & $\mathbf{+ 1 , 6 8}$ \\
\hline $\mathrm{pH}$ & 4.3 & 5 & 6 & 7 & 7.7 \\
Temperature $\left({ }^{\circ} \mathrm{C}\right)$ & 28.6 & 32 & 37 & 42 & 45.4 \\
Initial Moisture $(\%)$ & 51.6 & 55 & 60 & 65 & 68.4 \\
\hline
\end{tabular}


Table 2. Central Composite Design $\left(2^{3}\right)$ assays with 3 repetitions in the central point.

\begin{tabular}{cccc}
\hline Assay & pH & Temperature $\left({ }^{\circ} \mathbf{C}\right)$ & Initial Moisture (\%) \\
\hline $\mathbf{1}$ & -1 & -1 & -1 \\
$\mathbf{2}$ & +1 & -1 & -1 \\
$\mathbf{3}$ & -1 & +1 & -1 \\
$\mathbf{4}$ & +1 & +1 & -1 \\
$\mathbf{5}$ & -1 & -1 & +1 \\
$\mathbf{6}$ & +1 & -1 & +1 \\
$\mathbf{7}$ & -1 & +1 & +1 \\
$\mathbf{8}$ & +1 & +1 & +1 \\
$\mathbf{9}$ & -1.68 & 0 & 0 \\
$\mathbf{1 0}$ & +1.68 & 0 & 0 \\
$\mathbf{1 1}$ & 0 & -1.68 & 0 \\
$\mathbf{1 2}$ & 0 & +1.68 & 0 \\
$\mathbf{1 3}$ & 0 & 0 & -1.68 \\
$\mathbf{1 4}$ & 0 & 0 & +1.68 \\
$\mathbf{1 5}$ & 0 & 0 & 0 \\
$\mathbf{1 6}$ & 0 & 0 & 0 \\
$\mathbf{1 7}$ & 0 & 0 & 0 \\
\hline
\end{tabular}

\section{Culture Medium Preparation}

First, "crueira" suffered a heat treatment at $60^{\circ} \mathrm{C}$ for 18 hours. Then, it was crushed and the particles size was standardized on $1 \mathrm{~mm}$. Next, ten grams of treated "crueira" were transferred to a $125 \mathrm{ml}$ Erlenmeyer flask. Separately, nutrient solution (composed by $0.4 \mathrm{~g} / \mathrm{L} \mathrm{ZnSO}_{4}, 1.0 \mathrm{~g} / \mathrm{L} \mathrm{MgSO}_{4}, 1.5 \mathrm{~g} / \mathrm{L} \mathrm{KH}_{2} \mathrm{PO}_{4}, 0.5 \mathrm{~g} / \mathrm{L}$ $\mathrm{CaCl}_{2}, 0.1 \mathrm{~g} / \mathrm{L} \mathrm{FeSO}_{4}$ and $1.5 \mathrm{~g} / \mathrm{L}$ yeast extract) and buffer solution (citrate-phosphate buffer solution) volumes were added into test tubes to obtain the required $\mathrm{pH}$ and the amount of water necessary to obtain the desired moisture (deducting the amount of water present in the bacterial inoculum). The contents of the flasks and test tubes were autoclaved for sterilization at $121^{\circ} \mathrm{C}$ and $1 \mathrm{~atm}$ for 15 minutes. After autoclaving, the tube contents were poured into the Erlenmeyer flasks in a laminar flow cabinet. Next, $5.0 \mathrm{~mL}$ of the bacterial inoculum were added to the sterilized culture medium to start the solid-state fermentation. The flasks were transferred to a water bath to maintain the required temperature.

\section{Extraction and Quantitative Analysis of Amylases}

Amylases were extracted in 24, 48 and 72 hours for each assay using $1 \%(\mathrm{w} / \mathrm{v}) \mathrm{NaCl}$ solution based on salting-in effect principles. To extract the enzyme, $50 \mathrm{ml}$ of the $\mathrm{NaCl}$ solution $1 \%(\mathrm{w} / \mathrm{v})$ were added to the fermentation medium. The medium was shaked at $100 \mathrm{rpm}$ for 1 hour and then the liquid portion was centrifuged for 15 minutes at $4200 \mathrm{rpm}$. The supernatant from the centrifugation was used for quantitative assays. The quantification was conducted by the technique of dextrinizing activity with some modifications [8]. In a test tube, $2.0 \mathrm{ml}$ of the enzyme supernatant was added to $2.0 \mathrm{~mL}$ of $10 \mathrm{~g} / \mathrm{L}$ starch solution and 1.6 $\mathrm{ml}$ of acetate buffer $\mathrm{pH} 5.0$ and incubated in a water bath at $55^{\circ} \mathrm{C}$ for 25 minutes. Then, $1.0 \mathrm{~mL}$ of the test tube content were transferred to a $50 \mathrm{~mL}$ volumetric flask and the enzymatic hydrolysis was stopped by adding a $1.0 \mathrm{M}$ acetic acid solution. $2 \mathrm{ml}$ of an iodine solution $\left(1 \%(\mathrm{w} / \mathrm{v}) \mathrm{I}_{2}\right.$ solution in absolute ethanol, $10 \%(\mathrm{w} / \mathrm{v}) \mathrm{KI}$ in water and distilled water in the ratio $1 \mathrm{v}$ : $1 \mathrm{v}$ : $3 \mathrm{v}$, respectively) were added to the volumetric flask and it had its volume adjusted. The samples absorbance was measured at $600 \mathrm{~nm}$ and converted to milligrams of starch with a standard curve, previously made. One unit of amylolytic activity is defined as the amount of enzyme required to hydrolyze $0.33 \mathrm{mg}$ per minute of reaction [8].

\section{Amylolytic Enzymes Production Kinetics}

To evaluate the amylolytic enzymes production kinetics, it was prepared the same solid-state fermentation medium, using the production optimal conditions. Every 24 hours, one of the mediums had its enzymes extracted for the enzymatic quantification by dextrinizing activity [8]. 


\section{Enzymatic Characterization}

The effects of temperature, metal ions and $\mathrm{pH}$ were studied. For the temperature assay, the enzymatic extract was submitted to different temperatures $\left(25,35,45,55,65,75,85,95\right.$ and $\left.100^{\circ} \mathrm{C}\right)$ at pH 5.0 and 10 $\mathrm{g} / \mathrm{L}$ starch solution for 25 minutes, using $2 \mathrm{~mL}$ of enzymatic extract. For $\mathrm{pH}$ assay, the enzymatic extract was tested in different $\mathrm{pH}$ 's $(3,4,5,6,7$ and 8$)$ at $55^{\circ} \mathrm{C}$ and $10 \mathrm{~g} / \mathrm{L}$ starch solution for 25 minutes and using $2 \mathrm{~mL}$ of enzymatic extract. For the metal ions assay, Metal ions solutions $\left(\mathrm{Hg}^{2+}, \mathrm{Cu}^{2+}, \mathrm{Co}^{2+}, \mathrm{Ca}^{2+}, \mathrm{Zn}^{2+}, \mathrm{Fe}^{2+}, \mathrm{K}^{+}\right.$, $\mathrm{Mn}^{2+}, \mathrm{Mg}^{2+}$, all of them in a $0.1 \mathrm{~g} / \mathrm{L}$ concentration) were added to the enzyme activity test to assess their effects. The assays for metal ions effect were conducted at $\mathrm{pH} 5.0,55^{\circ} \mathrm{C}, 10 \mathrm{~g} / \mathrm{L}$ starch solution for 25 minutes, using $2 \mathrm{~mL}$ of enzymatic extract. The results were arranged in conservation of enzymatic activity relative to blank test (no ions added).

\section{RESULTS AND DISCUSSION}

In Table 3, it is the maximum enzyme activity was reached at 72 hours of fermentation and its value was $437.76 \mathrm{U} / \mathrm{g}$ of crueira, which is equivalent to $87.55 \mathrm{U} / \mathrm{mL}$ of enzymatic extract. According to Pandey and coauthors, the genus of bacteria with better production of amylase are Bacillus, however filamentous fungi are those which are the main sources for the biological production of enzymes [9]. The results presented in Table 3 are superior to Bhangue and coauthors (4.61 to $27.9 \mathrm{U} / \mathrm{ml}$ ) and less than Vijayaraghavan and coauthors (464 U/mL), both studies were developed using Bacillus. Dar and coauthors produced amylase from fungi obtaining $550.0 \mathrm{U} / \mathrm{mL}$ in 6 days fermentation $[10,11,12]$.

Table 3. CCD results in 24, 48 and 72 hours of fermentation using enzymatic activity as response variable.

\begin{tabular}{cccc}
\hline & \multicolumn{3}{c}{ Amylolytic Activity (U/g) } \\
\hline Assay & $\mathbf{2 4}$ hours & $\mathbf{4 8}$ hours & $\mathbf{7 2}$ hours \\
\hline $\mathbf{1}$ & 33 & 45.48 & 45.12 \\
$\mathbf{2}$ & 27.84 & 42.24 & 64.56 \\
$\mathbf{3}$ & 39.24 & 36.72 & 39.6 \\
$\mathbf{4}$ & 35.28 & 38.76 & 38.52 \\
$\mathbf{5}$ & 30 & 44.4 & 43.32 \\
$\mathbf{6}$ & 25.32 & 47.64 & 97.2 \\
$\mathbf{7}$ & 42.6 & 30.84 & 43.68 \\
$\mathbf{8}$ & 38.88 & 25.32 & 45.84 \\
$\mathbf{9}$ & 32.28 & 12.84 & 20.52 \\
$\mathbf{1 0}$ & 28.68 & 57.6 & 63.48 \\
$\mathbf{1 1}$ & 63.12 & 42.12 & 78.48 \\
$\mathbf{1 2}$ & 129.84 & 141.24 & 113.28 \\
$\mathbf{1 3}$ & 30.48 & 42.96 & 26.4 \\
$\mathbf{1 4}$ & 37.08 & 126.12 & 220.92 \\
$\mathbf{1 5}$ & 100.56 & 220.2 & 404,76 \\
$\mathbf{1 6}$ & 103.08 & 238.2 & 416.88 \\
$\mathbf{1 7}$ & 107.16 & 256.2 & 437.76 \\
\hline
\end{tabular}

As the maximum of enzymes produced, following the CCD, was achieved in 72 hours, the results of enzyme production in 72 hours were chosen for statistical analysis in the software STATISTICA. The software built, from the data provided, a table containing statistical data as effects, determination coefficient $\left(R^{2}\right)$ and standard error.

In Table 4, all variables had their quadratic terms significant to the probability of $95 \%$, the linear term of initial moisture was the only linear significant term in these conditions. 
Table 4. Regression coefficients for 72 hours of fermentation.

\begin{tabular}{|c|c|c|c|c|c|c|c|}
\hline Factor & Effect & Std. Err. & $p$ value & Coefficient & $\begin{array}{l}\text { Std. Err. } \\
\text { Coeff. }\end{array}$ & $\begin{array}{c}-95 \% \\
\text { Confidence } \\
\text { Limit }\end{array}$ & $\begin{array}{c}+95 \% \\
\text { Confidence } \\
\text { Limit }\end{array}$ \\
\hline Mean/Interc. & 420.752 & 23.83894 & 0.000000 & 420.752 & 23.83894 & 364.382 & 477.122 \\
\hline $\mathrm{pH}(\mathrm{L})$ & 21.476 & 22.38994 & 0.369410 & 10.738 & 11.19497 & -15.734 & 37.210 \\
\hline $\mathrm{pH}(\mathrm{Q})$ & -273.704 & 24.64339 & 0.000011 & -136.852 & 12.32169 & -165.988 & -107.716 \\
\hline $\begin{array}{l}\text { Temperature } \\
{ }^{\circ} \mathrm{C}(\mathrm{L})\end{array}$ & -3.520 & 22.38994 & 0.879527 & -1.760 & 11.19497 & -28.232 & 24.712 \\
\hline $\begin{array}{l}\text { Temperature } \\
{ }^{\circ} \mathbf{C}(\mathbf{Q})\end{array}$ & -235.605 & 24.64339 & 0.000029 & -117.803 & 12.32169 & -146.939 & -88.667 \\
\hline $\begin{array}{c}\text { Initial } \\
\text { Moisture \%(L) }\end{array}$ & 54.095 & 22.38994 & 0.046362 & 27.047 & 11.19497 & 0.576 & 53.519 \\
\hline $\begin{array}{c}\text { Initial } \\
\text { Moisture \%(Q) }\end{array}$ & -215.962 & 24.64339 & 0.000051 & -107.981 & 12.32169 & -137.117 & -78.845 \\
\hline 1Lby $2 \mathrm{~L}$ & -18.060 & 29.25386 & 0.556542 & -9.030 & 14.62693 & -43.617 & 25.557 \\
\hline 1Lby $3 \mathrm{~L}$ & 9.420 & 29.25386 & 0.756849 & 4.710 & 14.62693 & -29.877 & 39.297 \\
\hline 2Lby 3L & -4.860 & 29.25386 & 0.872750 & -2.430 & 14.62693 & -37.017 & 32.157 \\
\hline
\end{tabular}

Note: (L) and (Q) stand for linear and quadratic effects, respectively. The statistically significant values, at $95 \%$ probability, are bolded.

Equation 1 is obtained from the coefficients values for each variable, presented in Table 4, and describes the activity expected by the model as a function of the coded variables, considering only statistically significant terms.

$$
A(P, T, M)=420.752-136.852 P^{2}-117.803 T^{2}+27.048 M-107.981 M^{2}
$$

$A=$ Amylolytic Activity in 72 hours

$\mathrm{P}=\mathrm{pH}$

$\mathrm{T}=$ Temperature

$M=$ Initial Moisture

Table 5 presents the Analysis of variance (ANOVA) and it shows a high significant regression coefficient $(p<0.0001)$. The percentage of variance explained was $96.48 \%$ and adjusted explained variation percentage was $91.99 \%$, both satisfactory, considering that in biotechnological processes, the amount of errors and variations are likely to be high. In addition, the value of $F_{\text {calculated }}(76.83)$ is greater than the value of $F_{\text {tabulated }}$ $\left(F_{4,12}=3.26\right)$, which ensures the validation of the model, by the F-test.

Table 5. ANOVA for the response of the enzyme activity in 72 hours.

\begin{tabular}{ccccc}
\hline $\begin{array}{c}\text { Source of } \\
\text { variation }\end{array}$ & $\mathrm{SQ}$ & $\begin{array}{c}\text { Degrees of } \\
\text { freedom }\end{array}$ & Mean Squared & $\mathrm{F}_{\text {cal }}$ \\
\hline Regression & 329141 & 4 & 82285 & \\
Residues & 12858 & 12 & 1071 & \\
TOTAL & 341999,0 & 16 & & 76,83 \\
\hline 0,$96497 ; R^{2}$ adjusted $=91,993$ & & &
\end{tabular}

From Figure 1, it is evident the influence of the quadratic terms of all variables in this CCD. The maximum enzymatic activity was obtained at the midpoint of the three variables. 
(a)

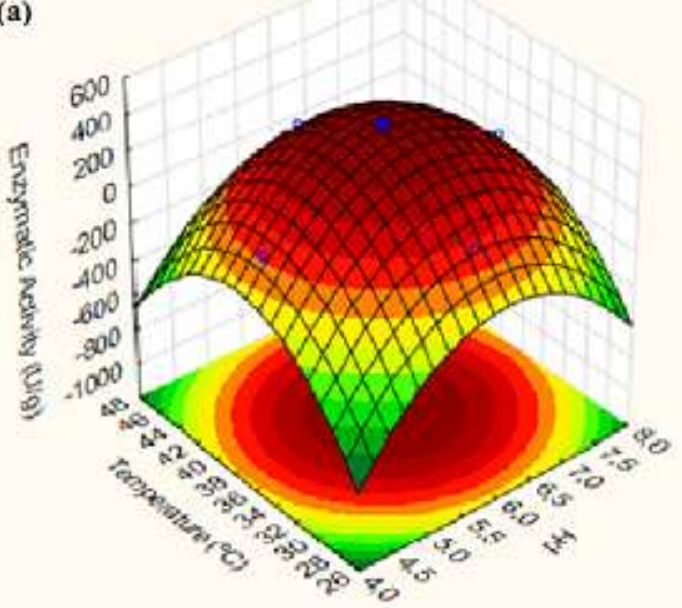

(b)

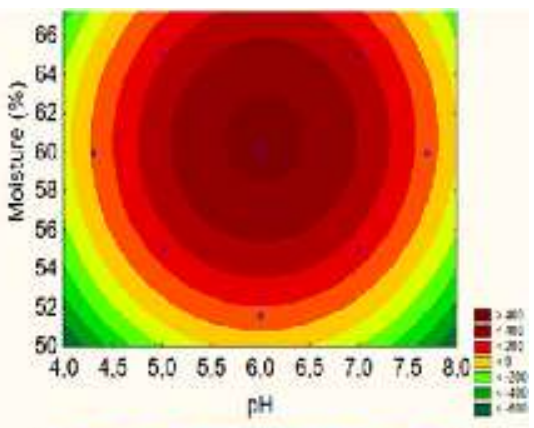

(c)

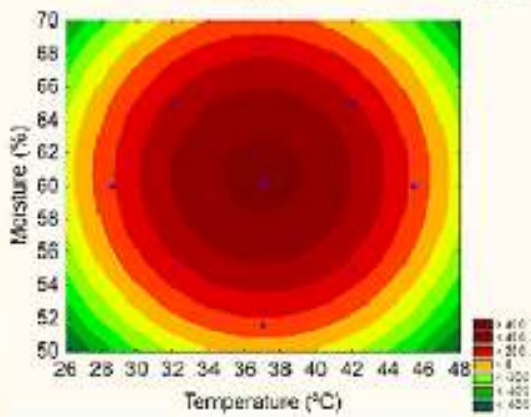

Figure 1. (a) Enzymatic activity dependent of $\mathrm{pH}$ and temperature, (b) Enzymatic activity dependent on initial moisture and $\mathrm{pH},(\mathrm{c})$ Enzymatic activity dependent of initial moisture and temperature.

\section{Amylolytic enzymes production kinetics}

The results for the enzyme kinetics assay are shown in Figure 2.

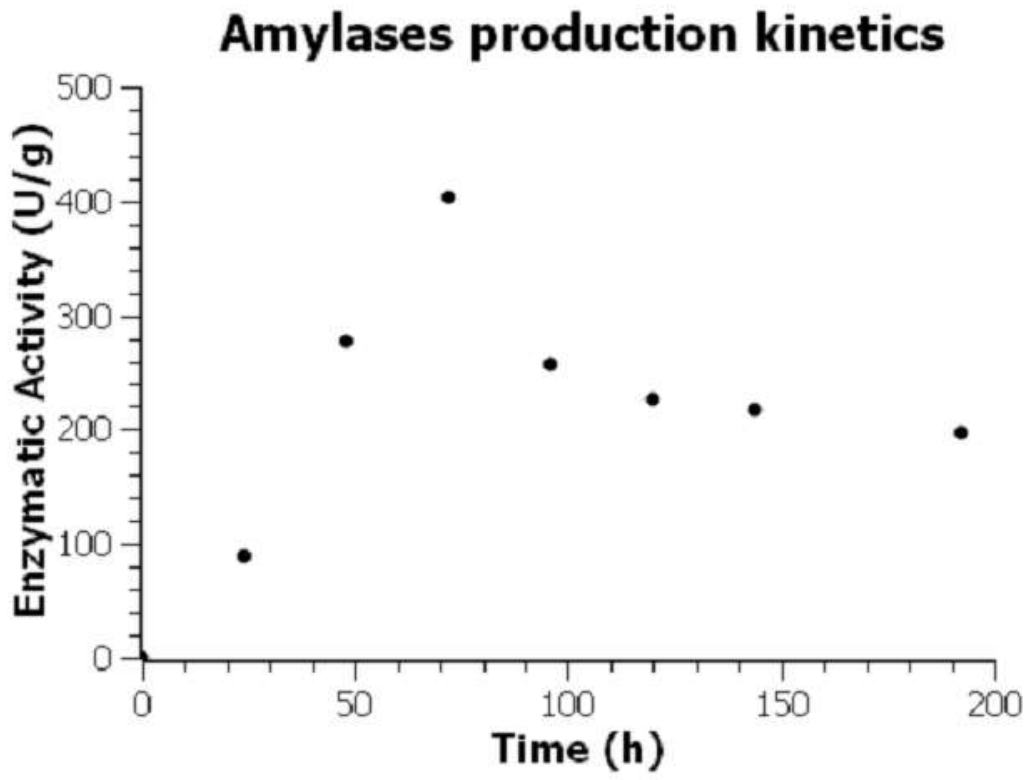

Figure 2. Kinetics for the amylases production.

There is a moderate increase in enzyme activity in the first 24 hours. In the first 48 hours, it is observed an exponential growth of this activity, reaching its peak in 72 hours. This phenomenon is commonly reported in the literature related to the production of amylases. The loss of activity after 72 hours, possibly is related to the bacteria population decline associated with the $\mathrm{pH}$ decrease. This decrease in activity can be happening because this bacterium may be releasing considerable amounts of carboxylic acids as a byproduct of glucose fermentation into acetoin (confirmed by Voges-Proskauer test). Thus, with the release of glucose in starch hydrolysis, the amount of carboxylic acids in the medium increases, leading to acidification and, consequently, the loss of amylase activity. Other unknown metabolites generated may be inhibiting the enzyme activity, as well. After the 96 hours, it is possible to notice a mild decrease, reaching plateau [13]. 
When comparing the results with literature was obtained similar data to Vijayaraghavan and coauthors (72 h) and lower production time Dar and coauthors (144h) and Bhangue and coauthors (96 h) $[10,11,12]$.

\section{Enzymatic characterization}

The produced amylases have a non-linear dependence on the temperature (Figure 3). It is possible to observe that the activity grows until the $65^{\circ} \mathrm{C}$-a peak- and decreases after this temperature, when it is observed no enzyme activity at $95^{\circ} \mathrm{C}$. Therefore, the optimum temperature for enzymatic activity is between $55^{\circ} \mathrm{C}$ and $65^{\circ} \mathrm{C}$, but the enzymes have good activity between 45 and $55^{\circ} \mathrm{C}$ as well.

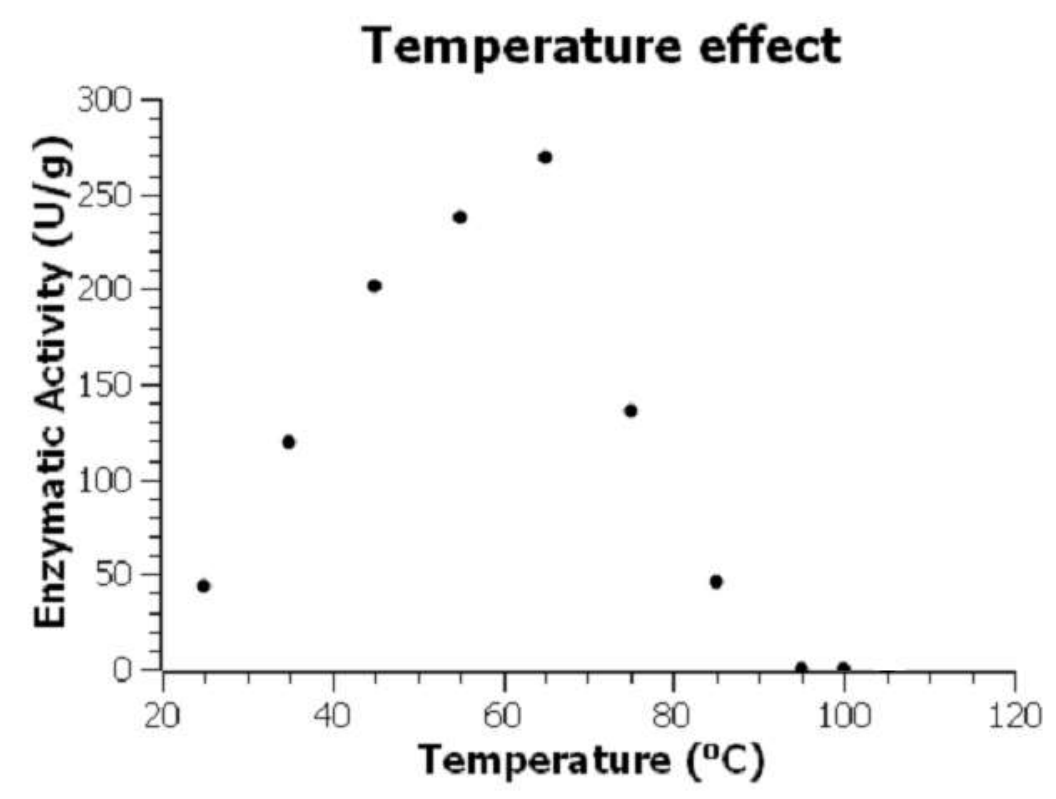

Figure 3. Graphic for temperature effect on amylases activity.

Also, the amylases showed $\mathrm{pH}$ resistance against $\mathrm{pHs}$ between 4 and 6 , shown in Figure 4 . Values greater than 6 and less than 4 had a sudden drop in activity. At pH 3, the activity decreased $65.90 \%$, at pH 7, 33.42\% and $\mathrm{pH} 8,78.56 \%$.

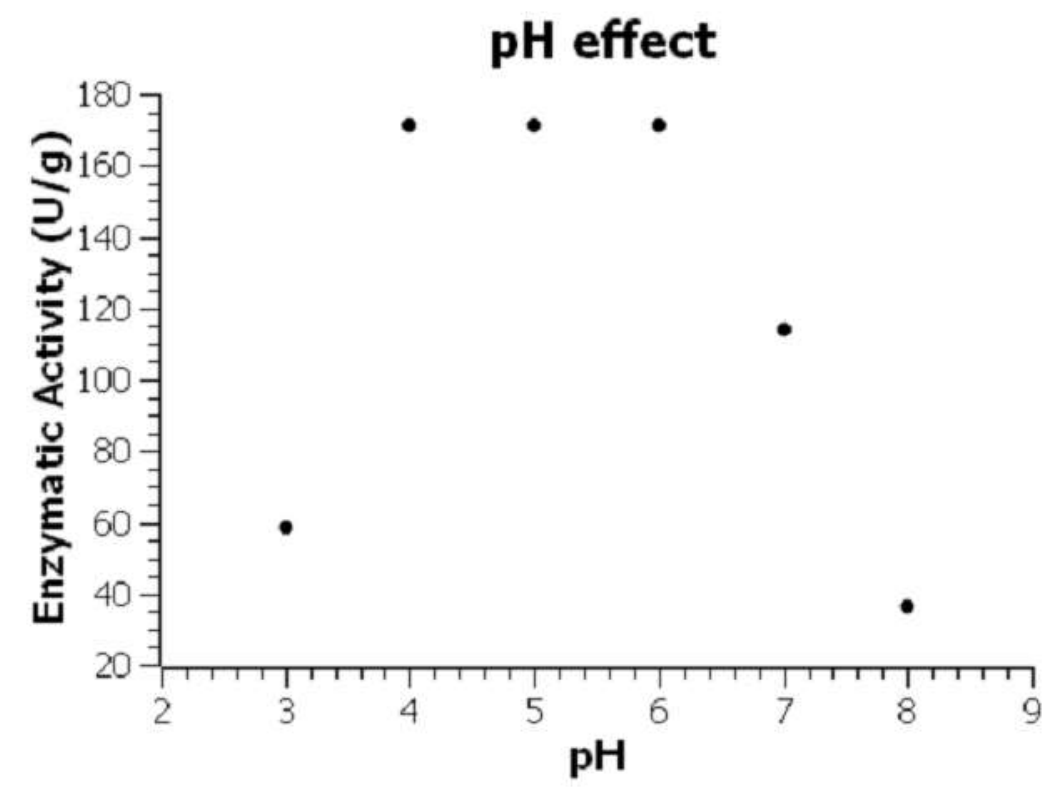

Figure 4. Graphic for pH effect on amylase activity. 
In literature, optimum $\mathrm{pH}$ and temperature values are quite varied. Bhangue and coauthors., using Bacillus subtilis, got optimum $\mathrm{pH}$ and temperature of 6.0 and $70{ }^{\circ} \mathrm{C}$, respectively. Vijayaraghavan and coauthors, using Bacillus cereus, observed optimum pH equal to 7.0 and $50{ }^{\circ} \mathrm{C}$ as optimum temperature. Awasthi and coauthors, studying amylase production from Bacillus cereus and Bacillus licheniformis, found that both amylases had $60^{\circ} \mathrm{C}$ as optimum temperature and a pH 6.5 for $B$. cereus and a $\mathrm{pH}$ range from 6 to 8 for $B$. licheniformis $[10,12,14]$. Some conditions found in those works were similar to the ones presented in this work. Still, some variations are observed and that is because each organism, even in the same Genus, has different genes to encode amylases production, therefore, the behavior of each amylase upon different conditions will be different as well.

The influence of metal ions on the amylase activity is quite varied (Figure 5). $\mathrm{Co}^{2+}, \mathrm{K}^{+}$and $\mathrm{Ca}^{2+}$ gave an increase in enzymatic activity. The positive influence of $\mathrm{Ca}^{+2}$ was expected, since it is an inorganic cofactor of amylolytic enzymes. The ferrous ion had neutral influence on activity, while the $\mathrm{Mg}^{2+}$ ions and $\mathrm{Hg}^{2+}$ had very little negative impact. The fact of amylase presenting most of its activity in presence of mercury is notorious, once it is a strong enzyme inhibitor - as in the case of urease - due to its heavy metal characteristic. $\mathrm{Mn}^{2+}$ and $\mathrm{Zn}^{2+}$ had an average negative effect, while the $\mathrm{Cu}{ }^{2+}$ ion showed strong enzyme inhibition.

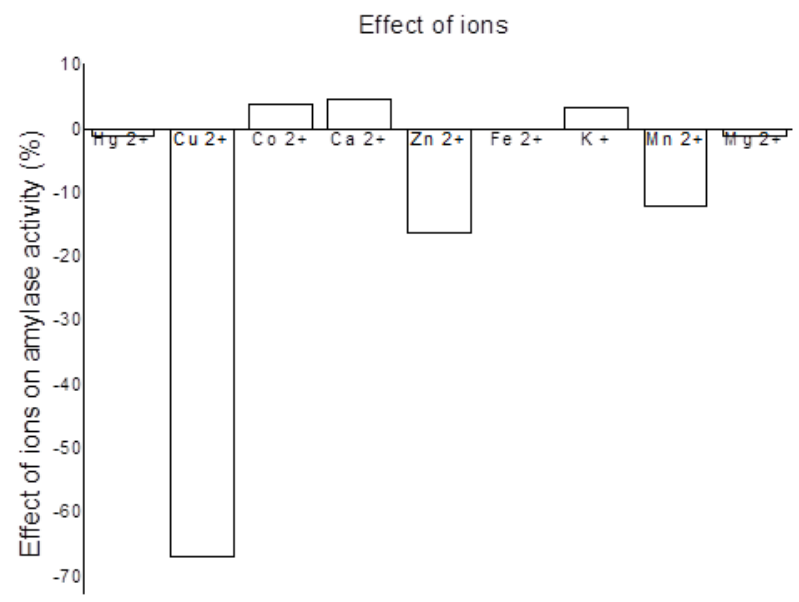

Figure 5. Graphic for different metal ions effect on amylases activity.

\section{CONCLUSION}

Crueira has shown itself as a good substrate for amylases production in solid state fermentation. In addition, the bacterium (Bacillus sp.) showed good adaptation to the solid-state fermentation conditions. The yield was effective, reaching maximum $437.76 \mathrm{U} / \mathrm{g}$ (equivalent to $87.55 \mathrm{U} / \mathrm{mL}$ of crude enzyme extract). In addition, there is a strong dependency on the optimum condition point $\left(\mathrm{pH} 6,37^{\circ} \mathrm{C}\right.$ and initial moisture $\left.60 \%\right)$ for the best production of amylolytic enzymes. For the enzyme characterization, the results were close to those found in the literature using Bacillus, hydrolyzing starch better in slightly acid $\mathrm{pH}$ range (4-6) and temperatures close to $65^{\circ} \mathrm{C}$.

Funding: This research was funded by COPES/UFS.

Conflicts of Interest: The authors declare no conflict of interest. The funders had no role in the design of the study; in the collection, analyses, or interpretation of data; in the writing of the manuscript, or in the decision to publish the results.

\section{REFERENCES}

1. Abd-Elhalem BT, El-Sawy M, Gamal RF, Abou-Taleb KA. Production of amylases from Bacillus amyloliquefaciens under submerged fermentation using some agro-industrial by-products. Ann Agr Sci. 2015 Dec; 60(2): 193-202. doi:10.1016/j.aoas.2015.06.001.

2. Joshi S, Satyanarayana T. In vitro engineering of microbial enzymes with multifarious applications: Prospects and perspectives. Bioresource Tecnol. 2015 Jan;176:273-283. doi:10.1016/j.biortech.2014.10. 
3. Vermelho AB, Cardoso V, Nascimento RP, Pinheiro AS, Rodrigues IA. Application of Microbial Enzymes in the Food Industry. In: V Ravishankar Rai, editor. Advances in Food Biotechnology. First Edition. John Wiley \& Sons; 2016. p. 107- 110.

4. Chaddad F. The Economics and Organization of Brazilian Agriculture: Recent Evolution and Productivity Gains. First Edition. London: Academic Press; 2016.

5. Ferreira-Leitão V, Gottschalk LMF, Ferrara MA, Nepomuceno AL, Molinari HBC, Bon EPS. Biomass Residues in Brazil: Availability and Potential Uses. Waste Biomass Valoriz. 2010 Mar; 65-76. doi: 10.1007/s12649-010-90088.

6. Cereda MP, Takahashi M. Cassava Wastes: Their characterization, and uses and treatment in Brazil. In: Dufour D, O'Brien GM, Best R, editors. Cassava flour and starch: progress in research and development. Cali: CIAT; 1996. p. 221-232.

7. Silva CF, Silva BCR, Gois IM, Bispo DF, Marques JJ. [Isolation and screening of microorganisms that produce enzymes of commercial interest]. Scientia Plena. 2018 Feb; 14 (2). doi: 10.14808/sci.plena.2018.024201.

8. Sanoja RR, Morlon-Guyot J, Jore J, Pintado J, Juge N, Guyot JP. Comparative Characterization of Complete and Truncated Forms of Lactobacillus amylovorus a-Amylase and Role of the C-Terminal Direct Repeats in Raw-Starch Binding. Appl Environ Microbiol. 2000 Aug; 66:8 p. 3350-3356. doi:10.1128/AEM.66.8.3350-3356.2000.

9. Pandey A, Nigam P, Soccol CR, Soccol VT, Singh D, Mohan R. Advances in microbial amylases. Biotechnol Appl Biochem. 2000 May; 31 (2) p. 135-152. doi: 10.1042/BA19990073.

10. Bhange K, Chaturvedi V, Bhatt R. Simultaneous production of detergent stable keratinolytic protease, amylase and biosurfactant by Bacillus subtilis PF1 using agro industrial waste. Biotechnol Rep. 2016 Jun; 10: p. 94-104. doi: 10.1016/j.btre.2016.03.007.

11. Dar GH, Kamili AN, Nazir R, Bandh SA, Janc TR, Chishti MZ. Enhanced production of $\alpha$-amylase by Penicillium chrysogenum in liquid culture by modifying the process parameters. Microb Pathog. 2015 Nov; 88: p 10-15. doi: 10.1016/j.micpath.2015.07.016.

12. Vijayaraghavan $P$, Kalaiyarasi M, Vincent SGP. Cow dung is an ideal fermentation medium for amylase production in solid-state fermentation by Bacillus cereus. J Genet. Eng Biotechnol., 2015 Dec; 13(2): p. 111-117. doi: 10.1016/j.jgeb.2015.09.004.

13. Hill JE, Gottschalk M, Brousseau R, Harel J, Hemmingsen SM, Goh SH. Biochemical analysis, cpn60 and 16S rDNA sequence data indicate that Streptococcus suis serotypes 32 and 34, isolated from pigs, are Streptococcus orisratti. Vet Microbiol. 2005 Apr 25; 107(1-2): p. 63-69. doi: 10.1016/j.vetmic.2005.01.003.

14. Awasthi MK, Wong JW, Kumar S, Awasthi SK, Wang Q, Wang M, Ren X, Zhao J, Chen H, Zhang Z. Biodegradation of food waste using microbial cultures producing thermostable $\alpha$-amylase and cellulase under different $\mathrm{pH}$ and temperature. Bioresource technology, v. 248, p. 160-170, 2018. doi: 10.1016/j.biortech.2017.06.160.

2020 by the authors. Submitted for possible open access publication under the terms and conditions of the Creative Commons Attribution (CC BY NC) license (https://creativecommons.org/licenses/by-nc/4.0/). 